\title{
Epidemiology and treatment of hepatitis $\mathrm{C}$ genotypes 5 and 6
}

\author{
Khalid AI Naamani MD FRCPC ${ }^{1}$, Siham Al Sinani MD FRCPC ${ }^{2}$, Marc Deschênes MD FRCPC 3
}

\begin{abstract}
K Al Naamani, S Al Sinani, M Deschênes. Epidemiology and treatment of hepatitis $\mathrm{C}$ genotypes 5 and 6. Can J Gastroenterol 2013;27(1):e8-e12.
\end{abstract}

Chronic hepatitis $\mathrm{C}$ infection is a major global health problem. The WHO estimates the number of infected people worldwide to be approximately 170 million. The estimated number of hepatitis $\mathrm{C}$ virus (HCV)-infected people in Canada is approximately 250,000, with approximately 5000 Canadians newly infected each year. Based on the identification of genomic differences, HCV has been classified into six HCV genotypes 1, 2 and 3 are widely distributed throughout the world and have been the focus of the majority of epidemiological, natural course and treatment studies. Although HCV genotypes 5 and 6 are prevalent in certain geographical areas, they are studied less extensively. HCV genotypes 5 and 6 are uncommon in Canada and account for less than $5 \%$ of $\mathrm{HCV}$-infected Canadians. However, immigration and travel can alter the epidemiology of these uncommon genotypes. The present article reviews and summarizes the available data regarding the epidemiology and treatment of HCV genotypes 5 and 6. Genotype 5 is endemic in the northern part of South Africa while genotype 6 is ment with a combination of pegylated interferon and ribavirin lead to a higher sustained virological response compared with HCV genotypes 1 and 4 . None of the approved direct-acting antiviral agents is currently recommended for the treatment of HCV genotypes 5 or 6 .

Key Words: Chronic; Hepatitis C; Genotype genotypes; genotype may influence the outcome of antiviral therapy. reported primarily in Asia. Available data show that 48 weeks of treat-

\section{L'épidémiologie et le traitement des génotypes 5 et 6 de l'hépatite $\mathrm{C}$}

L'infection par l'hépatite $\mathrm{C}$ chronique est un problème de santé majeur dans le monde. En effet, l'OMS estime qu'environ 170 millions de personnes sont infectées de par le monde. Ainsi, on estime qu'environ 250000 personnes sont infectées par le virus de l'hépatite C (VHC) au Canada, et que chaque année, environ 5000 Canadiens de plus sont infectés. D'après l'identification des différences génomiques, le VHC est classé en six génotypes, lesquels peuvent influer sur l'issue du traitement aux antiviraux. Les génotypes 1, 2 et 3 du VHC sont largement répartis dans le monde et ont fait l'objet de la majorité des études épidémiologiques, des études sur l'évolution naturelle et des études thérapeutiques. Même si les génotypes 5 et 6 du VHC sont prévalents dans certaines régions géographiques, on les étudie moins. Les génotypes 5 et 6 du VHC sont peu courants au Canada et représentent moins de $5 \%$ des Canadiens infectés par le VHC. Cependant, l'immigration et les voyages peuvent modifier l'épidémiologie de ces génotypes peu courants. Le présent article contient une analyse et un résumé des données disponibles au sujet de l'épidémiologie et du traitement des génotypes 5 et 6 du VHC. Le génotype 5 est endémique au nord de l'Afrique du Sud, tandis que le génotype 6 est surtout présent en Asie. Les données disponibles révèlent qu'un traitement de 48 semaines à l'aide d'une association d'interféron pégylé et de ribavirine suscite une réponse virologique soutenue plus élevée par rapport aux génotypes 1 et 4 du VHC. Aucun des antiviraux à action directe approuvés n'est actuellement recommandé pour le traitement des génotypes 5 ou 6 du VHC.

\section{HCV GENOTYPE 5}

hronic hepatitis $\mathrm{C}$ infection is a major global health problem. The WHO estimates the number of infected people worldwide to be approximately 170 million (1). The estimated number of hepatitis $\mathrm{C}$ virus (HCV)-infected people in Canada is approximately 250,000, with approximately 5000 Canadians newly infected each year (2).

$\mathrm{HCV}$ is an enveloped virus covering a single-stranded RNA genome approximately $10 \mathrm{~kb}$ in length corresponding to approximately 9400 nucleotides. Different HCV isolates from around the world show substantial nucleotide sequence variability throughout the viral genome (3). Based on the identification of these genomic differences, which can vary by as much as $35 \%$, HCV has been classifed into six genotypes that are numbered in the order of their discovery, with more than 70 subtypes that vary in their nucleotide sequence by at least $20 \%$ (4). Using sequence analysis of the core gene, studies conducted in the 1990s revealed that the most common genotype found in Canada is genotype 1, accounting for approximately $60 \%$ of cases, followed by genotypes 2 and 3. Genotypes 4, 5 and 6 account for less than $5 \%$ of cases (5-7). However, immigration, travel and greater cultural diversity have the potential to directly impact HCV epidemiology and may result in a higher number of Canadians being infected with previously uncommon genotypes 4, 5 and 6 . The present article reviews the available data regarding the epidemiology and treatment of HCV genotypes 5 and 6 .

\section{Epidemiology}

HCV genotype 5 has only one subtype: $5 \mathrm{a}$. It is found mainly in South Africa, where it accounts for $40 \%$ of HCV infections (8). The reported prevalences of $\mathrm{HCV}$ genotype 5 in different parts of the world are shown in Table 1. Pockets of HCV genotype 5 can be found worldwide. However, with the exception of South Africa, it is considered to comprise only a minor proportion of the HCV population. Nucleotide sequence analysis of the NS5B region was performed on $8479 \mathrm{HCV}$-positive patients from Quebec (15). Fifty-three patients had $\mathrm{HCV}$ genotype 5 , accounting for only $0.64 \%$ of cases. Most of these patients were females and were older than patients infected by other genotypes (15). Most of the studies describing HCV genotype 5 prevalence show no contact between endemic areas and the northern part of South Africa.

There are limited data available on the clinical, biological and pathological features of HCV genotype 5 infection. Most of the studies describing patients infected with HCV genotype 5 involve a small sample size, and most patients are women 50 years of age and older $(10,12,16)$, who tend to have a high viral load $\left(>10^{6}\right.$ copies $\left./ \mathrm{mL}\right)(17)$. The common identifiable transmission modes are iatrogenic, blood transfusion and intravenous drug use. Approximately 30\% of patients have cirrhosis at the time of presentation (17). One of the most

\footnotetext{
${ }^{1}$ Department of Medicine, Armed Forces Hospital; ${ }^{2}$ Department of Child Health, Sultan Qaboos University Hospital, Muscat, Oman; ${ }^{3}$ Department of Medicine, Division of Hepatology, Royal Victoria Hospital, McGill University Health Centre, Montreal, Quebec

Correspondence: Dr Siham Al Sinani, PC 121, PO Box 1438, Seeb, Oman. Telephone 968-99107770, fax 968-24550407,

e-mail siham_ss@hotmail.com

Received for publication January 22, 2012. Accepted June 24, 2012
} 
TABLE 1

Summary of hepatitis $\mathrm{C}$ virus genotype 5 prevalence

\begin{tabular}{llc}
\hline Author (reference) & Country & Prevalence, \% \\
\hline Smuts and Kannemeyer (8) & South Africa (northern) & 39.2 \\
Payan et al (9) & France (central) & 14.2 \\
Antaki et al (10) & Syria & 10 \\
Shobokshi et al (11) & Saudi Arabia & 1 \\
Antaki et al (12) & Canada (Montreal, Quebec) & 5 \\
D'Heygere et al (13) & Belgium & 4.2 \\
Jover et al (14) & Spain (southeast) & 10.3 \\
\hline
\end{tabular}

TABLE 2

Summary of studies describing treatment of hepatitis $C$ virus genotype 5

\begin{tabular}{|c|c|c|c|c|c|}
\hline $\begin{array}{l}\text { Author } \\
\text { (Reference) }\end{array}$ & $\begin{array}{l}\text { Study } \\
\text { design }\end{array}$ & $\begin{array}{c}\text { Patients, } \\
n\end{array}$ & Treatment & $\begin{array}{c}\text { Duration, } \\
\text { weeks }\end{array}$ & $\begin{array}{c}\text { SVR, } \\
\%\end{array}$ \\
\hline \multirow{2}{*}{$\begin{array}{l}\text { Bonny et al } \\
(20)\end{array}$} & \multirow[t]{2}{*}{ Retrospective } & 44 & IFN monotherapy & 48 & 31 \\
\hline & & 43 & Peg-IFN + ribavirin & 48 & 71 \\
\hline \multirow{2}{*}{$\begin{array}{l}\text { Legrand- } \\
\text { Abravanel } \\
\text { et al (21) }\end{array}$} & \multirow[t]{2}{*}{ Case control } & 3 & IFN-alpha + ribavirin & 48 & 63.6 \\
\hline & & 9 & Peg-IFN + ribavirin & & \\
\hline \multirow{2}{*}{$\begin{array}{l}\text { Bonny et al } \\
\text { (22) }\end{array}$} & \multirow[t]{2}{*}{ Retrospective } & 28 & IFN + ribavirin & 48 & 64 \\
\hline & & 59 & Peg-IFN + ribavirin & & 58 \\
\hline \multirow{2}{*}{$\begin{array}{l}\text { Antaki et al } \\
(23)\end{array}$} & \multirow[t]{2}{*}{ Retrospective } & 17 & IFN + ribavirin & $24-48$ & 47 \\
\hline & & 9 & Peg-IFN + ribavirin & & 67 \\
\hline
\end{tabular}

IFN Interferon; Peg-IFN Pegylated IFN; SVR Sustained virological response

important factors for the development of advanced liver disease is the duration of infection. Few studies have compared the prevalence of hepatocellular carcinoma (HCC) among different HCV genotypes; however, genotype does not appear to influence the development of HCV-associated HCC $(18,19)$.

\section{Treatment}

Data regarding treatment for HCV genotype 5 is scant. This is mainly due to the low prevalence of HCV genotype 5 worldwide. Due to the lack of data, HCV genotype 5 is generally regarded to have a low response rate to treatment with interferon (IFN)-alpha and ribavirin combination therapy, and treatment intensity as well as duration is similar to that for HCV genotype 1. Table 2 summarizes the studies describing treatment of HCV genotype 5.

One of the first studies describing the treatment of HCV genotype 5 was a retrospective study from France by Bonny et al (20). Patients were treated with standard IFN monotherapy, or a combination of standard IFN and ribavirin for 48 weeks. The sustained virological response (SVR) for standard IFN alone was lower than that for combination standard IFN and ribavirin (31\% versus $71 \%[\mathrm{P}<0.05])$. The SVR after 48 weeks of treatment was comparable with that of HCV genotypes 2 and 3. In a case control study by Legrand et al (21), 12 patients with HCV genotype 5 were treated with standard IFN plus ribavirin (three patients) or pegylated IFN (peg-IFN) with ribavirin (nine patients) for 48 weeks. The study reported that all patients had absence of detectable virus at 24 weeks of treatment and at the end of treatment (48 weeks). The SVR in patients infected with HCV genotype 5 was better than that in patients infected with HCV genotype 1 $(63.6 \%$ versus $22.7 \%$, respectively $[\mathrm{P}<0.05])$ despite high viral load in patients with $\mathrm{HCV}$ genotype 5 and was comparable with that in patients infected with HCV genotypes 2 or $3(66.6 \%)$. A retrospective study with a larger sample size $(n=87)$ with HCV genotype 5 was reported by Bonny et al (22). Twenty-eight patients were treated for 48 weeks with standard IFN ( 3 million units [MU] three times per week) plus ribavirin ( $800 \mathrm{mg} /$ day to $1200 \mathrm{mg} /$ day $)$ and 59 patients were treated for 48 weeks with peg-IFN alpha-2b (1.5 $\mu \mathrm{g} / \mathrm{kg} /$ week $)$ plus ribavirin $(800 \mathrm{mg} / \mathrm{kg}$ to $1200 \mathrm{mg} / \mathrm{kg})$. The overall SVR rate among patients with HCV genotype 5 was $60 \%$ (52 of 87 ). Thirty per cent (26 of 87 )
TABLE 3

Summary of the prevalence of hepatitis $C$ genotype 6 in Southeast Asia

\begin{tabular}{llc}
\hline Author (reference) & Country & Prevalence, \% \\
\hline Lao et al (25) & Hong Kong & $20-33$ \\
Nguyen et al (29) & Vietnam (south) & 36 \\
Kanistanon et al (30) & Thailand & 18 \\
Lwin et al (31) & Burma & 49 \\
Oh et al (32) & Korea & 1.4 \\
\hline
\end{tabular}

experienced relapse after the end of treatment response (ETR), they were older than those who achieved SVR and received lower doses of ribavirin. Ten per cent (nine of 87 ) were nonresponders and had the same baseline characteristics as the relapsers. There was no statistically significant difference between the SVR in patients treated with pegIFN and those treated with standard IFN. Antaki et al (23) conducted a retrospective study in which 26 patients with HCV genotype 5 were treated with ribavirin $1000 \mathrm{mg} /$ day to $1200 \mathrm{mg}$ /day plus either standard IFN or peg-IFN for 24 or 48 weeks. Fifty-four per cent demonstrated an SVR (47\% with standard IFN and $67 \%$ with peg-IFN $[\mathrm{P}=0.43])$. Younger patients with low viral load and milder histology had better results. There was no statistically significant difference with respect to SVR between those who were treated for 24 weeks compared with 48 weeks. This was the first study describing high SVR with shorter duration of treatment. However, caution must be exercised due to the small sample size, nonstandardized treatment and study design.

In summary, the above studies demonstrated that treatment of $\mathrm{HCV}$ genotype 5 with a combination of peg-IFN and ribavirin for 48 weeks resulted in high SVR (60\%), comparable with that of genotypes 2 and 3. Because treatment duration has not yet been established, large randomized clinical studies are required to determine the optimum duration of treatment. The available data to date suggest that treatment of HCV genotype 5 should consist of a combination of peg-IFN and ribavirin for 48 weeks. Response-guided therapy has not been studied in this patient population.

\section{Epidemiology}

\section{HCV GENOTYPE 6}

Most reports regarding HCV genotype 6 are from Asian countries including Hong Kong, Thailand, Indonesia, China, Vietnam, Myanmar and Korea (24-32) (Table 3). There are few reports of HCV genotype 6 in Australia, Canada and the United States, where most of these patients were immigrants from endemic areas. Murphy et al (15) reported that 146 of $8479 \mathrm{HCV}$-positive patient samples from Quebec were infected with genotype 6 , accounting for $1.8 \%$ of cases. The most prevalent subtype of genotype 6 was $6 e(40.4 \%)$. With the exception of three patients, all patients infected with HCV genotype 6 were of Asian origin. Spread of genotype 6 is expected to rise due to increasing immigration from endemic areas. Novel HCV genotypes 7, 8 and 9, found mainly in Vietnam, as well as genotype 11 found in Indonesia, are closely related to genotype 6 and have been reclassified as subtypes of genotype 6 (33). HCV genotype 6 has 21 subtypes assigned the letters a to $u$. Four new subtypes, $6 \mathrm{r}$ to $6 \mathrm{u}$, were discovered recently. With the exception of the 6 a subtype, most of the other subtypes are very rare, which could be partly due to incomplete sampling or low frequency. Data regarding risk factors for HCV genotype 6 are lacking. Similar to most HCV genotypes, unsafe therapeutic injections, intravenous drug use and blood transfusion are probable modes of transmission of $\mathrm{HCV}$ genotype 6 (12). Available data regarding clinical manifestations are scant. In one study (34), there were no differences found between HCV genotype 1 and 6 in liver biochemistry, titres, cirrhosis and risk for HCC.

\section{Treatment}

Most of the available data regarding treatment for HCV genotype 6 are based mainly on a few small nonrandomized trials. However, recently, two large randomized trials investigating the response rate to a combination of 
TABLE 4

\begin{tabular}{|c|c|c|c|c|c|}
\hline $\begin{array}{l}\text { Author } \\
\text { (Reference) }\end{array}$ & $\begin{array}{l}\text { Study } \\
\text { design }\end{array}$ & $\begin{array}{c}\text { Patients, } \\
\text { n }\end{array}$ & Treatment & Duration & $\begin{array}{c}\text { SVR, } \\
\%\end{array}$ \\
\hline Dev et al (35) & Prospective & 40 & IFN + ribavirin & 52 weeks & 83 \\
\hline Hui et al (36) & Prospective & 16 & IFN + ribavirin & 12 months & 62.5 \\
\hline \multirow{3}{*}{$\begin{array}{l}\text { Nugyen et al } \\
(37)\end{array}$} & \multirow[t]{3}{*}{ Retrospective } & 31 & IFN + ribavirin, or & 24 weeks & 51.6 \\
\hline & & 23 & Peg-IFN + ribavirin, & 24 weeks & 39 \\
\hline & & 12 & or peg-IFN + ribavirin & 48 weeks & 75 \\
\hline Fung et al (38) & Retrospective & 21 & Peg-IFN + ribavirin & 48 weeks & 86 \\
\hline \multirow[t]{2}{*}{ Lam et al (39) } & Open-label & 27 & Peg-IFN + ribavirin & 24 weeks & 70 \\
\hline & RCT & 33 & Peg-IFN + ribavirin & 48 weeks & 79 \\
\hline \multirow[t]{2}{*}{$\begin{array}{c}\text { Tangkijvanich } \\
\text { et al (40) }\end{array}$} & Pilot & $\begin{array}{c}25 \\
(\mathrm{RVR}+)\end{array}$ & Peg-IFN + ribavirin & 24 weeks & 88 \\
\hline & & $\begin{array}{c}9 \\
(\mathrm{RVR}-)\end{array}$ & Peg-IFN + ribavirin & 48 weeks & 44 \\
\hline \multirow{2}{*}{$\begin{array}{l}\text { Thu Thuy } \\
\text { et al (41) }\end{array}$} & Open-label & 70 & Peg-IFN + ribavirin & 48 weeks & 71 \\
\hline & $\mathrm{RCT}$ & 35 & Peg-IFN + ribavirin & 24 weeks & 60 \\
\hline
\end{tabular}

IFN Interferon; Peg-IFN Pegylated IFN; RCT Randomized controlled trial; $R V R+/-$ Rapid virological response positive or negative; SVR Sustained virological response

peg-IFN and ribavirin in HCV genotype 6 as well as optimal duration of treatment have been published (Table 4). One of the earliest studies describing the treatment of HCV genotype 6 was by Dev et al (35). Forty patients received ribavirin ( $1 \mathrm{~g}$ daily for patients weighing $\leq 75 \mathrm{~kg}$ or $1.2 \mathrm{~g}$ daily for those weighing $>75 \mathrm{~kg}$ ). Patients with genotypes 1 and 6 received either an induction dose of standard IFN 5 MU daily for eight weeks followed by 3 MU three times weekly for 44 weeks or a dose of $3 \mathrm{MU}$ three times weekly for 52 weeks. The authors reported an SVR of $83 \%$ in patients treated with standard IFN with ribavirin. Hui et al (36) prospectively compared the effect of IFN and ribavirin combination therapy in HCV genotypes 1 and 6 . Of the 40 patients included, 16 had genotype 6 and 24 had genotype 1 . Patients received standard IFN $5 \mathrm{MU}$ three times weekly plus oral ribavirin $1.0 \mathrm{~g} /$ day in two divided doses if weighing $\leq 75 \mathrm{~kg}$ and $1.2 \mathrm{~g} /$ day if weighing $>75 \mathrm{~kg}$ for 12 months. An SVR was achieved in 10 (62.5\%) patients with genotype 6 and in seven (29.2\%) patients with genotype 1 . The same study demonstrated regression in fibrosis stage in four $(25 \%)$ patients with genotype 6 and one $(6.3 \%)$ patient with genotype $1(\mathrm{P}=0.2)$. Another retrospective study by Nguyen et al (37), in which 66 treatment-naive Asian-American patients with genotype 6 received either 24 weeks of standard IFN and ribavirin (31 patients), or peg-IFN and ribavirin (23 patients), or 48 weeks of peg-IFN and ribavirin (12 patients), demonstrated no significant difference in SVR after 24 weeks of treatment between the group receiving standard IFN and ribavirin compared with the group treated with peg-IFN and ribavirin $(51.6 \%$ versus $39 \%$ $[\mathrm{P}=0.363])$. However, the SVR in 12 patients treated with 48 weeks of peg-IFN and ribavirin was significantly higher than that in those treated with peg-IFN and ribavirin for 24 weeks (75\% versus 39\% [P=0.044]). The off-treatment relapse rate was $35 \%$ for the 24 -week group compared with $17 \%$ for the 48 -week group. A retrospective study by Fung et al (38) included 42 patients with HCV who were naive to IFN treatment. Twenty-one patients infected with HCV genotype 1 were compared with 21 patients infected with HCV genotype 6. Both groups were treated with a combination of ribavirin and peg-IFN for 12 months. Treatment was stopped prematurely in six patients due to side effects. The study demonstrated that there was a significant difference in SVR (86\% for genotype 6 versus $52 \%$ for genotype 1 [P $\leq 0.019]$ ).

A larger multicentre, open-label randomized controlled study by Lam et al (39) involving 60 patients randomly assigned to peg-IFN with ribavirin for either 24 weeks (27 patients) or 48 weeks (33 patients) showed a high SVR in both groups (70\% in the 24-week group and $79 \%$ in the 48 -week group $[\mathrm{P}=0.45])$. Patients treated for 48 weeks required more erythropoietin for anemia compared with patients treated for 24 weeks. The SVR was similar to randomized controlled trials involving an HCV genotype 1 in an Asian population. The authors suggested that combination therapy with peg-IFN alpha-2a and ribavirin for 24 weeks for HCV genotype 6 would be acceptable for patients who cannot tolerate 48 weeks of therapy. There are no reported studies investigating the response rate among different subtypes of genotype 6 .

A pilot study evaluated treatment response on the basis of rapid virological response of $\mathrm{HCV}$ genotype 6 compared with genotypes 1 and 3. An SVR was achieved in $62.5 \%, 81.3 \%$ and $76.5 \%$ of patients with genotypes 1, 3 and 6, respectively. The SVR rate in patients with genotype 6 who underwent response-guided therapy was $88 \%$ (40). A recent, large open-label randomized trial from Vietnam involved $105 \mathrm{HCV}$ genotype 6-infected patients who were randomly assigned to either 48 weeks (70 patients) or 24 weeks (35 patients) of peg-IFN alpha-2a and ribavirin therapy. Ninety-two patients completed the study (63 in the 48-week and 29 in the 24-week group). There was no statistical difference between the SVR in the two groups (71\% for the 48-week group versus $60 \%$ for the 24 -week group [P=0.24]) (41). These studies demonstrated that 48 weeks of treatment of HCV genotype 6 using a combination of peg-IFN and ribavirin resulted in a higher SVR compared with that of genotype 1 and approached the SVR reported for genotypes 2 and 3 . The two recent randomized trials $(39,41)$ revealed that 24 weeks of peg-IFN and ribavirin treatment resulted in SVRs comparable with 48 weeks of treatment. Reduced treatment time can be used in patients intolerant to treatment and those who achieve rapid virological response. Larger studies are required to demonstrate the noninferiority of shorter-duration therapy before the recommendation of 24 weeks of therapy.

\section{INTERLEUKIN-28B POLYMORPHISM}

Recent genome-wide association studies revealed that host genetic variation is associated with hepatitis $C$ treatment response as well as spontaneous clearance of the virus. Different single-nucleotide polymorphisms in the interleukin (IL)-28 B gene in chromosome 19 coding for type III IFN-lambda had been found to be associated with HCV treatment response (42-44). Allele frequencies differ among ethnic groups, and this may explain the observed differences in response rates among Caucasians, African Americans and Asians. Studies have reported high response rates in the Asian population $(35,45)$. High response rates in Asian patients with HCV genotype 6 could, in part, be due to IL-28 B polymorphism. However, none of the studies on the treatment of HCV genotype 5 and 6 examined the IL-28 B polymorphism as a response predictor.

\section{DIRECT-ACTING ANTIVIRAL AGENTS}

A better understanding of the viral cycle has led to the development of direct-acting antiviral agents (DAA). Two DAA, telaprevir and boceprevir - oral protease inhibitors targeting the NS3/NS4A region of the virus genome - have been approved in combination with pegIFN and ribavirin in the treatment of HCV genotype $1(46,47)$. Because the structure of the NS3/4A protease is different among HCV genotypes, protease inhibitors have different antiviral efficacy for different genotypes. The two approved HCV genotype 1 protease inhibitors boceprevir and telapravir are not approved for HCV genotypes 5 and 6; therefore, peg-IFN and ribavirin currently remain the treatment of choice for both genotypes. Development of wider spectrum DAA, such as NS5A or entry inhibitors, may lead to other agents that could be used to treat patients with HCV genotypes 5 and 6 .

\section{SUMMARY}

HCV genotypes 5 and 6 are uncommon in Canada and are endemic in the northern part of South Africa (genotype 5) and in certain parts of Asia (genotype 6). Due to the impact of globalization, the epidemiology of these uncommon genotypes is expected to change. Response of HCV genotypes 5 and 6 to 48 weeks of treatment with combination INF and ribavirin is better than that for genotypes 1 and 4. Until additional data are available, the recommended duration of treatment is 48 weeks. None of the new DAA are approved for the treatment of HCV genotypes 5 or 6 . 
AUTHOR CONTRIBUTIONS: Khalid Al Naamani: first author, study concept and design, data acquisition and review supervision. Siham Al Sinani: corresponding author, analysis and interpretation of data, drafting of the manuscript. Marc Deschênes: critical revision of the manuscript for important intellectual content and material support.

\section{REFERENCES}

1. Lauer GM, Walker BD. Hepatitis $C$ virus infection. N Engl J Med 2001;345:41-52.

2. Public Health Agency of Canada. A study to characterize the epidemiology of hepatitis C infection in Canada, 2002. Final report. 2004. Ottawa: Health Canada; 2004

3. Choo QL, Richman KH, Han JH, et al. Genetic organization and diversity of the hepatitis C virus. Proc Natl Acad Sci U S A 1991;88:2451-5.

4. Simmonds P, Bukh J, Combet C, et al. Consensus proposals for a unified system of nomenclature of hepatitis $\mathrm{C}$ virus genotypes. Hepatology 2005;42:962-73.

5. Andonov A, Chaudhary RK. Genotyping of Canadian hepatitis C virus isolates by PCR. J Clin Microbiol 1994;32:2031-4.

6. Murphy DG, Willems B, Delage G, et al. Hepatitis C virus genotypes in patients and blood donors - Quebec. Can Commun Dis Rep 1995;21:129-32.

7. Bernier L, Willems B, Delage G, Murphy DG. Identification of numerous hepatitis $\mathrm{C}$ virus genotypes in Montreal, Canada. J Clin Microbiol 1996;34:2815-8.

8. Smuts HE, Kannemeyer J. Genotyping of hepatitis C virus in South Africa. J Clin Microbiol 1995;33:1679-81.

9. Payan C, Roudot-Thoraval F, Marcellin P, et al. Changing of hepatitis $\mathrm{C}$ virus genotype patterns in France at the beginning of the third millenium: The GEMHEP GenoCII Study. J Viral Hepat 2005;12:405-13.

10. Antaki N, Haddad M, Kebbewar K, et al. The unexpected discovery of a focus of hepatitis $\mathrm{C}$ virus genotype 5 in a Syrian province. Epidemiol Infect 2009;137:79-84.

11. Shobokshi OA, Serebour FE, Skakni L, Al-Saffy YH, Ahdal MN. Hepatitis C genotypes and subtypes in Saudi Arabia. J Med Virol 1999;58:44-8

12. Antaki N, Craxi A, Kamal S, et al. The neglected hepatitis C virus genotypes 4, 5 and 6: An international consensus report. Liver Int 2010;30:342-55.

13. D'Heygere F, George C, Van Vlierberghe, et al. Efficacy of interferon-based antiviral therapy in patients with chronic hepatitis C infected with genotype 5: A meta-analysis of two large prospective clinical trials. J Med Virol 2011;83:815-9.

14. Jover R, Pérez-Serra J, de Vera F, et al. Infection by genotype 5a of $\mathrm{HCV}$ in a district of southeast Spain. Am J Gastroenterol 2001;96:3042-3.

15. Murphy DG, Willems B, Deschênes M, Hilzenrat N, Mousseau R, Sabbah S. Use of sequence analysis of the NS5B region for routine genotyping of hepatitis $\mathrm{C}$ virus with reference to $\mathrm{C} / \mathrm{E} 1$ and $5^{\prime}$ untranslated region sequences. J Clin Microbiol 2007;45:1102-12.

16. Abergel A, Ughetto S, Dubost S, et al. The epidemiology and virology of hepatitis $\mathrm{C}$ virus genotype 5 in central France. Aliment Pharmacol Ther 2007;26:1437-46.

17. Murphy DG, Willems B, Vincelette J, Bernier L, Côté J, Delage G. Biological and clinicopathological features associated with hepatitis C virus type 5 infections. J Hepatol 1996;24:109-13.

18. Kedda MA, Kew MC, Coppin A. Hepatocarcinogenic potential of genotype 5 of hepatitis C virus. Trop Gastroenterol 1997;18:153-5.

19. Reid AE, Koziel MJ, Aiza I, et al. Hepatitis C virus genotypes and viremia and hepatocellular carcinoma in the United States. Am J Gastroenterol 1999;94:1619-26.

20. Bonny C, Roche C, Randl K, et al. Treatment of interferon-naive patients with HCV genotype 5 with interferon (or PEG-interferon) plus ribavirin results in a very high sustained viral response. Hepatology 2003;38:738.

21. Legrand-Abravanel F, Sandres-Sauné K, Barange K, et al. Hepatitis $\mathrm{C}$ virus genotype 5: Epidemiological characteristics and sensitivity to combination therapy with interferon-alpha plus ribavirin. J Infect Dis 2004;189:1397-400.

22. Bonny C, Fontaine H, Poynard T, et al. Effectiveness of interferon plus ribavirin combination in the treatment of naive patients with hepatitis $\mathrm{C}$ virus type 5 . A French multicentre retrospective study. Aliment Pharmacol Ther 2006;24:593-600.
23. Antaki N, Hermes A, Hadad M, et al. Efficacy of interferon plus ribavirin in the treatment of hepatitis $C$ virus genotype 5 . J Viral Hepat 2008;15:383-6.

24. Mellor J, Walsh EA, Prescott LE, et al. Survey of type 6 group variants of hepatitis $C$ virus in Southeast Asia by using a corebased genotyping assay. J Clin Microbiol 1996;34:417-23.

25. Lao W, Li FT, Youde P, Prevalence of genotype 6 chronic hepatitis $\mathrm{C}$ infection in Hong Kong. Hepatology 2001;34:A689.

26. Sugiyama K, Kato N, Nakazawa T, et al. Novel genotypes of hepatitis C virus in Thailand. J Gen Virol 1995;76:2323-7.

27. Tokita H, Okamoto H, Iizuka $\mathrm{H}$, et al. Hepatitis $\mathrm{C}$ virus variants from Jakarta, Indonesia classifiable into novel genotypes in the second (2e and 2f), tenth (10a) and eleventh (11a) genetic groups. J Gen Virol 1996;77:293-301.

28. Lu L, Nakano T, He Y, Fu Y, Hagedorn CH, Robertson BH. Hepatitis $\mathrm{C}$ virus genotype distribution in China: Predominance of closely related subtype $1 \mathrm{~b}$ isolates and existence of new genotype 6 variants. J Med Virol 2005;75:538-49.

29. Nguyen MH, Trinh H, Garcia RT, et al. High prevalence of novel genotypes in Vietnamese patients with chronic hepatitis C. Gastroenterology 2004;126:2020A.

30. Kanistanon D, Neelamek M, Dharakul T, Songsivilai S. Genotypic distribution of hepatitis $\mathrm{C}$ virus in different regions of Thailand. J Clin Microbiol 1997;35:1772-6.

31. Lwin AA, Shinji T, Khin M, et al. Hepatitis C virus genotype distribution in Myanmar: Predominance of genotype 6 and existence of new genotype 6 subtype. Hepatol Res 2007;37:337-45.

32. Oh HB, Kim SO, Cha CH, et al. Identification of hepatitis C virus genotype 6 in Korean patients by analysis of 5' untranslated region using a matrix assisted laser desorption/ ionization time of flight-based assay, restriction fragment mass polymorphism. J Med Virol 2008;80:1712-9.

33. Mizokami M, Gojobori T, Ohba K, et al. Hepatitis C virus types 7 , 8 and 9 should be classified as type 6 subtypes. J Hepatol 1996;24:622-4.

34. Seto WK, Lai CL, Fung J, et al. Interim analysis of the natural history of chronic hepatitis $\mathrm{C}$ genotype 1 and 6 . Hepatology 2008;48:1102A.

35. Dev AT, McCaw R, Sundararajan V, Bowden S, Sievert W. Southeast Asian patients with chronic hepatitis C: The impact of novel genotypes and race on treatment outcome. Hepatology 2002;36:1259-65

36. Hui CK, Yuen MF, Sablon E, Chan AO, Wong BC, Lai CL. Interferon and ribavirin therapy for chronic hepatitis $\mathrm{C}$ virus genotype 6: A comparison with genotype 1. J Infect Dis 2003;187:1071-4.

37. Nguyen MH, Trinh HN, Garcia R, Nguyen G, Lam KD, Keeffe EB. Higher rate of sustained virologic response in chronic hepatitis $\mathrm{C}$ genotype 6 treated with 48 weeks versus 24 weeks of peginterferon plus ribavirin. Am J Gastroenterol 2008;103:1131-5.

38. Fung J, Lai CL, Hung I, et al. Chronic hepatitis C virus genotype 6 Infection: Response to pegylated interferon and ribavirin. J Infect Dis 2008;198:808-12.

39. Lam KD, Trinh HN, Do ST, et al. Randomized controlled trial of pegylated interferon-alfa $2 \mathrm{a}$ and ribavirin in treatment-naive chronic hepatitis C genotype 6. Hepatology 2010;52:1573-80.

40. Tangkijvanich P, Komolmit P, Mahachai V, Poovorawan K, Akkarathamrongsin S, Poovorawan Y. Response-guided therapy for patients with hepatitis $\mathrm{C}$ virus genotype 6 infection: A pilot study. J Viral Hepat 2012;19:423-30.

41. Thu Thuy PT, Bunchorntavakul C, Tan Dat H, Rajender Reddy K. A randomized trial of 48 versus 24 weeks of combination pegylated interferon and ribavirin therapy in genotype 6 chronic hepatitis C. J Hepatol 2012;56:1012-8.

42. Ge D, Fellay J, Thompson AJ, et al. Genetic variation in IL28B predicts hepatitis $C$ treatment-induced viral clearance. Nature 2009;17;461:399-401.

43. Suppiah V, Moldovan M, Ahlenstiel G, et al. IL28B is associated with response to chronic hepatitis $\mathrm{C}$ interferonalpha and ribavirin therapy. Nat Genet 2009;41:1100-4. 
44. Tanaka Y, Nishida N, Sugiyama M, et al. Genome-wide association of IL28B with response to pegylated interferon-alpha and ribavirin therapy for chronic hepatitis C. Nat Genet 2009;41:1105-9.

45. Liu CH, Liu CJ, Lin CL, et al. Pegylated interferon-alpha-2a plus ribavirin for treatment-naive Asian patients with hepatitis $C$ virus genotype 1 infection: A multicenter, randomized controlled trial. Clin Infect Dis 2008;47:1260-9.
46. Jacobson IM, McHutchison JG, Dusheiko G, et al. Telaprevir for previously untreated chronic hepatitis $\mathrm{C}$ virus infection. N Engl J Med 2011;364:2405-16.

47. Poordad F, McCone J Jr, Bacon BR, et al. Boceprevir for untreated chronic HCV genotype 1 infection. N Engl J Med 2011;364:1195-206. 


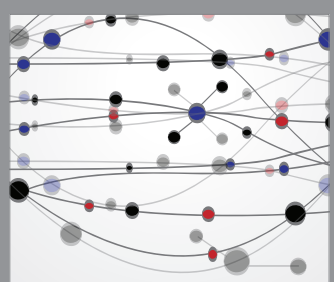

The Scientific World Journal
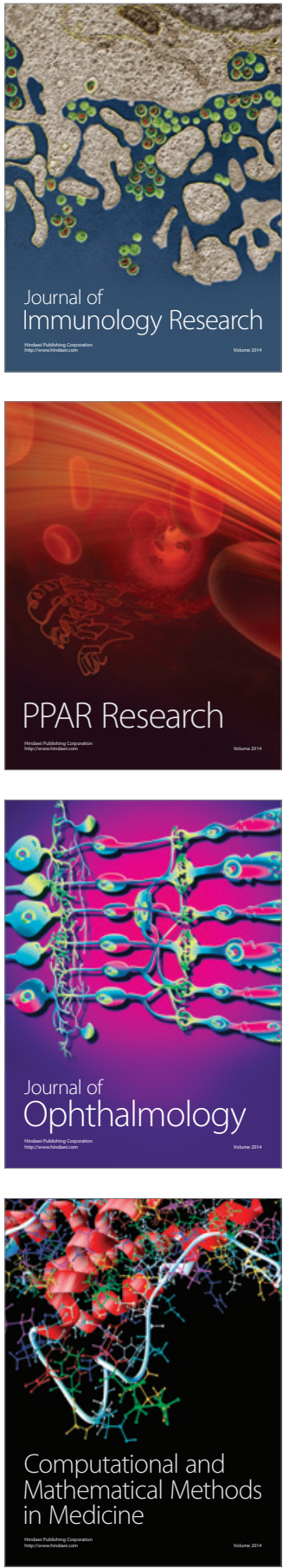

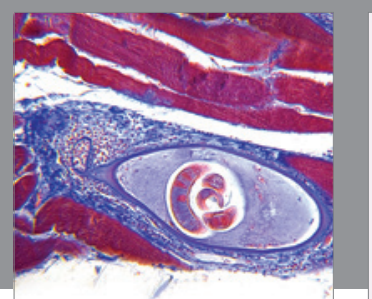

Gastroenterology Research and Practice

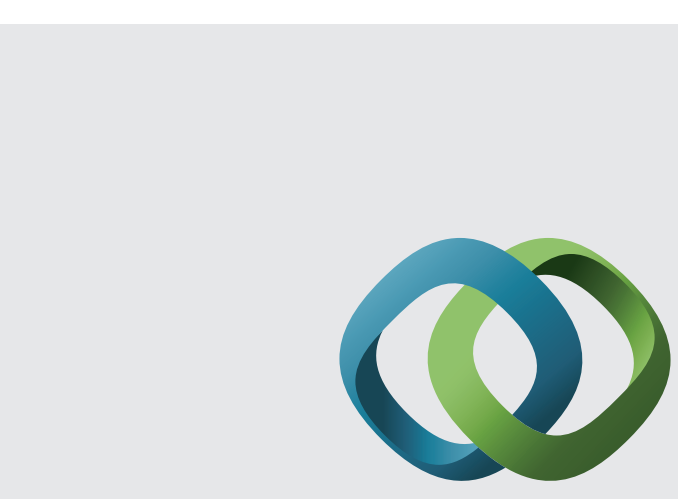

\section{Hindawi}

Submit your manuscripts at

http://www.hindawi.com
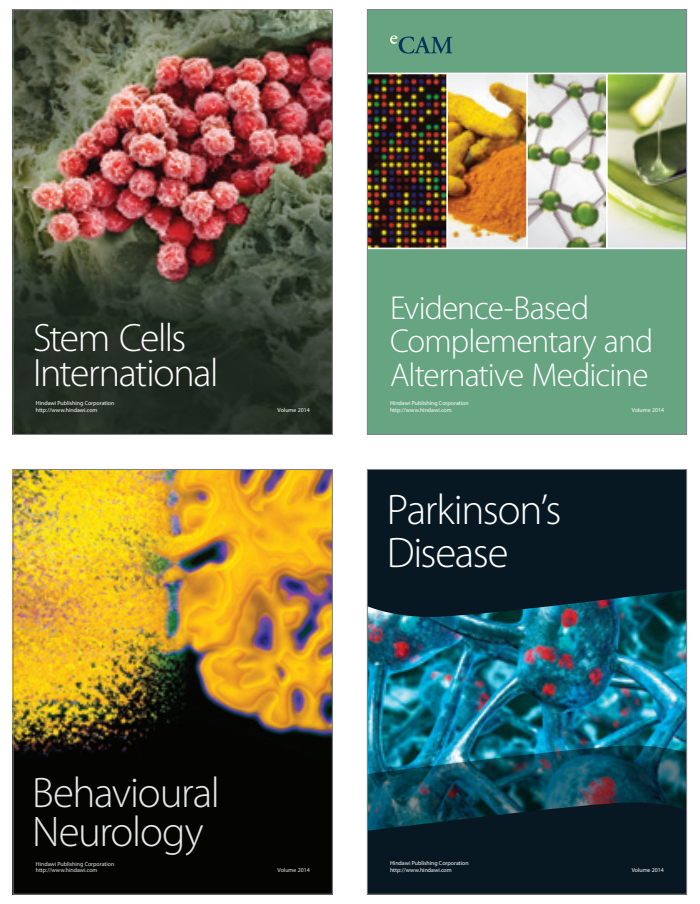
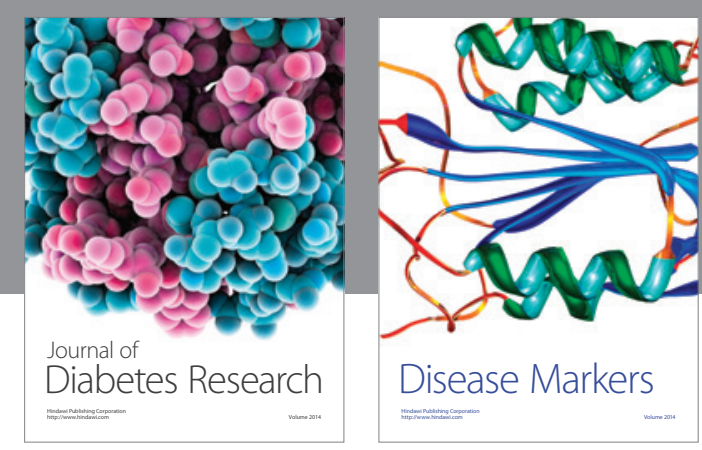

Disease Markers
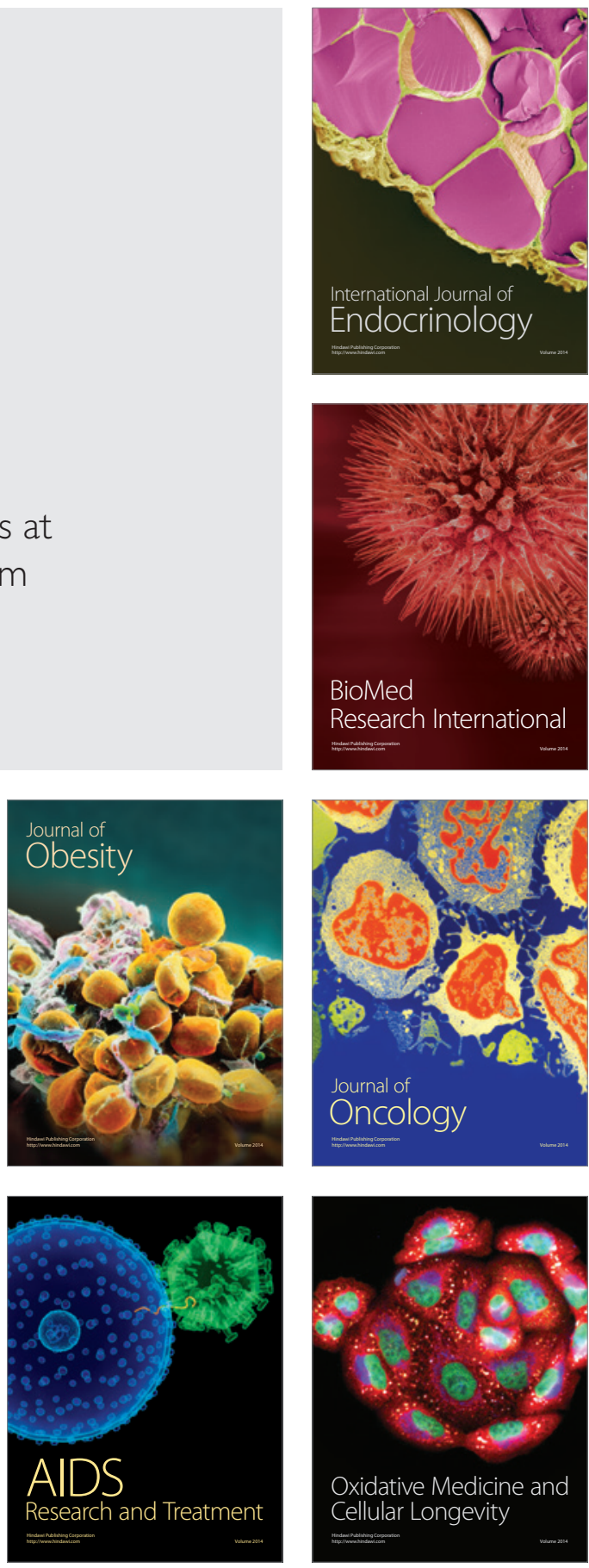